\title{
波浪中の船体に働く 垂直曲げモーメントの設計值推定
}

\author{
正員 新 開 明 二* \\ Estimating the Design Values of Vertical Bending Moment \\ Induced on the Ship Hull in Waves
}

by Akiji Shinkai, Member

Summary

The statistical predictions of vertical wave bending moment were made for a gigantic oil tanker of 310 meters length and the similar ships of different lengths, in order to find out the long-term trends of vertical wave bending moment and to examine the design values of those.

Firstly, the response functions of vertical wave bending moment were calculated by the aid of the modified strip theory. Then, the standard deviations of vertical wave bending moment for different short-term sea conditions were evaluated based upon the linear superposition theory, by using the calculated response functions and the formulated wave spectra for given sea conditions. Finally, the long-term predictions of vertical wave bending moment were determined by using the obtained standard deviations of vertical wave bending moment for the individual short-term sea conditions and the wave statistics of the North Atlantic Ocean.

According to the systematic prediction works, the longitudinal distributions of vertical wave bending moment predicted with the exceeding probability of $10^{-8}$ are investigated in relation to the ship speed and heading angle, and the predicted results were compared with the design values of vertical wave bending moment given by the different classification societies.

\section{1 楮言}

船体縦強度設計においては, 船の大型化と船体構造の合理化のために垂直波浪剪断力及び曲げォーメント，水 平波浪顡断力及び曲げモーメント，波浪捩りモーメント等の波浪荷重について，その設計值の推定が必要になっ ている。福田等 ${ }^{1)}$ は巨大型油送船を計算適用例として, 船体に働く垂直波浪剪断力の応答関数の計算, 標準偏差 の計算，長期予測計算を実施し，これらの計算結果より垂直波浪剪断力設計值推定のための資料を得ている。

そこで，本論文においては，文献 1）で採用された巨大型油送船を計算適用例として，船体に働く垂直波浪曲 げモーメントに関して長期予測等を実施して,その設計值推定に関する検討を行なった。

縦強度設計において重直波浪曲げモーメントが特に重要視されてきたので, 垂直波浪曲げモーメントに関する 研究は多数報告されている。福田等 ${ }^{2,3}$ による規則波中の高速艦艇及び大型油送船に働く垂直波浪曲げモーメン トの計算, 島田等 ${ }^{4}$ による大型油送船に動く垂直波浪曲げモーメントの規則波中及び不規則波中の計算が注目さ れる。また，長期予測に基づいて垂直波浪曲げモーメントの荷重設計值を定めようと試みた研究としては， Nordenström $^{5)}$, Abrahamsen ${ }^{6,7)}$, 福田 ${ }^{8,9,10)}$, Lewis ${ }^{11)}$ 等の研究報告がある。最近, 佐藤等 ${ }^{12)}$ は幅広巨大船の 構造強度を検討するに際して垂直波浪曲げモーメントの長期予測を行なっている。

しかしながら, 以上の多数の研究報告がなされているにもかかわらず, 最大值が生じると考えられる船体中央 断面に働く垂直波浪曲げモーメントに関する研究が主となっており，垂直波浪曲げモーメントの船長方向分布が

* 九州大学大学院工学研究科 
検討されている報告でね, 長期予測に基づく荷重設計值の船長方向分布, 船速及び波に対する迎角の影響, 船型 の大きさの影響等の性質を解明するには不十分であると思われる。本論文においては, 船長 $310 \mathrm{~m}$, 載荷重量 21 万トンの巨大型油送船について, 規則波中の垂直波浪曲げモーメント応答関数の計算, 短期不規則波中の垂直波 浪曲げモーメント標準偏差の計算, 北大西洋における垂直波浪曲げモーメント長期予測計算を実施し, さらに本 船型と船長の異なる相似船型を仮定して同様の計算を実施し，これらの計算結果より垂直波浪曲げモーメント設 計値の推定に関する検討を行なっている。

\section{2 計 算 方 法}

\section{1 規則波中の船体に働く垂直波浪曲げモーメント}

規則波中に执いて，船が波の進行方向に対して一定の平均針路を保ち一定速度で航行している場合を考兄る と，線形ストリップ理論を斜波中に拡張応用した計算法 ${ }^{13,14}$ によって，まず，上下摇と縦摇の連成運動方程式を 解き，次に，その上下摇と緥摇の解を用いて船体の長さ方向任意の位置の断面に働く垂直波浪曲げモーメントを 求めることができる。

すなわち, 上下摇 $\zeta$ と縦摇 $\phi$ の運動方程式は次式のように与えられる。

$$
\left.\begin{array}{l}
A_{11} \ddot{\xi}+A_{12} \dot{\xi}+A_{13} \zeta+A_{14} \ddot{\phi}+A_{15} \dot{\phi}+A_{16} \phi=F_{\zeta} \\
A_{21} \ddot{\xi}+A_{22} \dot{\xi}+A_{23} \zeta+A_{24} \ddot{\phi}+A_{25} \dot{\phi}+A_{26} \phi=M_{\phi}
\end{array}\right\}
$$

上下摇と綐摇の解は, 運動方程式 (1)を解いて次式の形で得られる。

$$
\left.\begin{array}{c}
\zeta=\zeta_{0} \cos \left(\omega_{e} t-\varepsilon_{\zeta}\right) \\
\phi=\phi_{0} \cos \left(\omega_{e} t-\varepsilon_{\phi}\right)
\end{array}\right\}
$$

ただし，

$$
\begin{aligned}
\zeta_{0}, \phi_{0} & : \text { amplitudes of heave and pitch } \\
\varepsilon_{\zeta}, \varepsilon_{\phi} & : \text { phase angles of heave and pitch } \\
\omega_{e} & : \text { circular frequency of wave encounter } \\
t & : \text { time }
\end{aligned}
$$

（2）で得られた運動の解を用いて重直波浪曲げモーメントを計算すれば，次式の形で求められる。

$$
M=M_{0} \cos \left(\omega_{e} t-\varepsilon_{M}\right)
$$

あるいは,

$$
\left[M / h_{0}\right]=\left[M_{0} / h_{0}\right] \cos \left(\omega_{e} t-\varepsilon_{M}\right)
$$

ただし，

$$
\begin{aligned}
& M_{0}: \text { amplitude of vertical wave bending moment } \\
& \varepsilon_{M}: \text { phase angle of vertical wave bending moment } \\
& h_{0}: \text { amplitude of surface wave }
\end{aligned}
$$

\section{2 不規則波中の船体に働く垂直波浪曲げモーメント}

有義波高 $H$, 平均波周期 $T$ の短期不規則波浪海面の波スペクトルを ISSC スペクトル15)で近似的に表わし， 波スペクトルの方向性分布は波の平均進行方向に対して $\pm 90^{\circ}$ の範囲に ( cosine $)^{2}$ 分布をすると仮定する。 すなわち，

$$
\begin{aligned}
& \left.\begin{array}{rl}
{[f(\omega, \gamma)]^{2}} & =(2 / \pi)[f(\omega)]^{2} \cos ^{2} \gamma:-\pi / 2<\gamma<\pi / 2 \\
& =0: \text { elsewhere }
\end{array}\right\} \\
& {[f(\omega)]^{2}=0.11 H^{2} \omega_{T}^{-1}\left(\omega / \omega_{T}\right)^{-5} \exp \left[-0.44\left(\omega / \omega_{T}\right)^{-4}\right]}
\end{aligned}
$$

ただし，

$$
\begin{aligned}
& \omega: \text { circular frequency of a component wave } \\
& r: \text { angle between the average wave direction and a component wave direction } \\
& H: \text { visually estimated average wave height } \\
& \omega_{T}=2 \pi / T, \quad T: \text { visually estimated average wave period }
\end{aligned}
$$

(5) 及び (6) で表わされる短期不規則波浪海面において船が一定速度を保ち且つ波の平均進行方向に対し一定 の針路を保って航行している場合を考えると，船体に働く垂直波浪曲げモーメントの分散 $R^{2}$ は (4)で得られた 
応答関数 $\bar{M}_{0}(\omega, \delta+\gamma)\left(=\left[M_{0} / h_{0}\right]\right)$ を用いて, 線形重ね合わせの理論 ${ }^{16)}$ そ基づくエネルギースペクトル計算によ り次式のように求められる。

$$
R^{2}=\int_{-\pi / 2}^{\pi / 2} \int_{0}^{\infty}[f(\omega, \gamma)]^{2}\left[\bar{M}_{0}(\omega, \delta+\gamma)\right]^{2} d \omega d \gamma
$$

ただし，

$R:$ standard deviation of vertical wave bending moment

$[f(\omega, \gamma)]^{2}:$ directional wave spectrum

$\bar{M}_{0}(\omega, \delta+\gamma)$ : response amplitude of vertical wave bending moment in regular waves from the direction of $\delta+\gamma$

$\delta:$ average heading angle against the average wave direction

\section{3 垂直波浪曲げモーメントの長期予測}

短期の不規則波浪海面において, 船が平均進行方向に対して一定の針路を保ち一定の速度で航行している場合 飞, 船体に働く垂淔波浪曲げモーメントの極大值がある一定值 $M_{1}$ を超える確率は次式で与えられる17)。

$$
q\left(M>M_{1}\right)=\exp \left[-M_{1}^{2} / 2 R^{2}\right]=\exp \left[-\frac{\left(M_{1} / \rho g L^{3} B\right)^{2}}{2\left(R / \rho g L^{2} B H\right)^{2}} \frac{L^{2}}{H^{2}}\right]
$$

ただし，

$$
\begin{aligned}
& \rho: \text { density of sea water } \\
& g: \text { acceleration of gravity } \\
& L: \text { ship length } \\
& B: \text { ship breadth }
\end{aligned}
$$

従って, 有義波高 $H$, 平均波周期 $T$ の波浪海面の長期発現確率密度関数 $p(H, T)$ が与兄られている海域を, 船が長期間にわたって常に一定の速度を保ち且つ波の平均進行方向に対して一定の平均迎角を保って航海するも のと仮定すれば, 船体に働く垂直波浪曲げモーメントの極大值がある一定值 $M_{1}$ を超える長期の累積確率は次式 によって求められる8,9,10)。

$$
\begin{aligned}
Q\left(M>M_{1}\right) & =\int_{0}^{\infty} \int_{0}^{\infty} q\left(M>M_{1}\right) p(H, T) d H d T \\
& =\int_{0}^{\infty} \int_{0}^{\infty} \exp \left[-\frac{\left(M_{1} / \rho g L^{3} B\right)^{2}}{2\left(R / \rho g L^{2} B H\right)^{2}} \frac{L^{2}}{H^{2}}\right] p(H, T) d H d T
\end{aligned}
$$

ただし，

$Q\left(M>M_{1}\right):$ long-term exceeding probability for a level $M_{1}$ of vertical wave bending moment at heading $\delta$

そこで, 船がある海域を長期間にわたって航海する場合に, 波の平均進行方向に対する船の平均迎角 $\delta$ の確率 密度関数が海面状態, 船速等にかかわらず常に $0 \sim 2 \pi$ の範囲に一様であると近似し得るならば, すべての迎角 を考虑した場合に船体に働く垂直波浪曲げモーメントの極大值がある值 $M_{1}$ を超 える長期の累積確率は (9) で 得られた $Q\left(M>M_{1}\right)$ を改めて $Q(\delta)$ と定義しなおして, 次式で与えられる。

$$
Q=(1 / 2 \pi) \int_{0}^{2 \pi} Q(\delta) d \delta
$$

ただし，

$Q$ : long-term exceeding probability for a level $M_{1}$ of vertical wave bending moment when all headings are considered

\section{3 計算結果及び考察}

上記の計算方法により，巨大型油送船船型について，まず規則波中の船体に働く垂直波浪曲げモーメントの応 答関数の計算を行ない，次に短期不規則波中の垂直波浪曲げモーメント標準偏差を計算し，最後に北大西洋の長 期波浪発現頻度を用いて垂直波浪曲げモーメントの長期予測を行なった。計算例として採用した船型の主要目を Table 1 に示す。また，この船型を基準船型とし，これと幾何学的に相似で船長が異なる数種類の船型を仮定し て，同様の計算を実施し垂直波浪曲げモーメントの長期予測を行なった。 


\section{1 垂直波浪曲げモーメントの応答関数}

規則波中の船体に働く垂直波浪曲げモーメントの応答関数の計算条件は次の通りである。

a) 船 速 $(V)$ $F_{r}=V / \sqrt{g L}=0,0.05,0.10,0.15$

b）波に対する船の迎角（ $\chi$ ) $\chi=0,22.5,45,67.5,90,112.5,135,157.5,180^{\circ}$ (追波状態を $\chi=0^{\circ}$ とする)

c) 波長 $(\lambda)$ $\sqrt{L / \lambda}=0.3 \sim 1.8$ (0.1 間隔)

d）垂直波浪曲げモーメントの計算を行なった断面位置

S.S. $1 ， 2 ， 3 ， 4 ， 5 ， 6 ， 7 ， 8 ， 9$ (船長の 10 等分位置)

Fig. 1 及び 2 に, 垂直波浪曲げモーメントの応答関数計算結果を例示する。垂直波浪曲げモーメントの無次元 振幅 $M_{0} / \rho g L^{2} B h_{0}$ を $\sqrt{L / \lambda}$ の関数として表わしており, Fig. 1 には, $F_{r}=0.15$ の場合に迎角 $\chi$ をパラメータ とした図を，Fig. 2 には， $\chi=180^{\circ}$ (迎波状態) の場合にフルード数 $F_{r}$ をパラメータとした因を示した。

\section{2 垂直波浪曲げモーメントの標準偏差}

（7）によって短期不規則波中の船体に働く垂直波浪曲げモーメントの標準偏差の計算を行なった。計算条件は 次の通りである。

a) 船速は 3.1 の場合と同じ条件

b ) 波の平均進行方向に対する船の迎角 $(\delta)$ $\delta=0,22.5,45,67.5,90,112.5,135,157.5,180^{\circ}$ (追波状態を $\delta=0^{\circ}$ とする)

c）平均波周期 $(T)$ $T=4,6,8,10,12,14,16,18 \mathrm{sec}$

d）垂直涋浪曲げモーメントの計算を行なった断面位置は 3.1 の場合と同じ条件

垂直波浪曲げモーメントの標準偏差計算を行ならにあたっては, 垂直波浪曲げモーメントの応答スペクトル数 值積分は文献 18)に説明した方法によって行なった。

Fig. 3 及び 4 汇，垂直波浪曲げモーメントの標準偏差計算結果を例示する。垂直波浪曲げモーメントの標準偏 差無次元值 $R / \rho g L^{2} B H$ を $\sqrt{L / \lambda_{e}}\left(\lambda_{e}=g T^{2} / 2 \pi\right)$ の関数として表わしており, Fig. 3 には, $F_{r}=0.15$ の場合に迎 角 $\delta$ をパラメータとした図を, Fig. 4 には, 迎角 $\delta=180^{\circ}$ (迎波状態) の場合にフルード数 $F_{r}$ をパラメータと した図を示した。

\section{3 垂直波浪曲げモーメントの長期予測結果}

北大西洋の長期波浪発現頻度資料を用いて船長 $310 \mathrm{~m}$ の巨大型油送船船型及びこれと幾何学的に相似で船長の 異なる船型（ $L=190 ， 250 ， 310 ， 370 ， 430 ， 490 \mathrm{~m}$ ）について垂值波浪曲げモーメントの長期予測を行なった。 計算条件は次の通りである。

a) 船速は 3.1 の場合と同じ条件

b ) 船の波汶対する迎角 $(\delta)$

$\delta=0,22.5,45,67.5,90,112.5,135,157.5,180^{\circ}$ の各場合及びすべての迎角を考慮した場合

c）玨直波浪曲げモーメントの計算を行なった断面位置は 3.1 の場合と同じ条件

d）波浪発現頻度

Walden ${ }^{19}$ 亿よる北大西洋の長期波浪発現頻度資料（北大西洋に扎いて 1950 年 1 月 1 日より 1959 年 12 月 31 日究で 10 年間にわたる 227,497 観測数の資料を, 有義波高 $H$ と平均波周期 $T$ の関数として区分 整理した波浪発現頻度表 ${ }^{10)}$ ) を用いた。

Fig. 5 飞, 船長 $310 \mathrm{~m}$ の船型について垂直波浪曲げモーメントの長期分布を求めた例を, Fig. 6 に, 船長 190 $\sim 490 \mathrm{~m}$ の 6 種類の船型について垂直波浪曲げモーメントの長期分布を求めた例を示す。Fig. 5 及び 6 に例示さ れたよらな長期分布図より，長期超過確率 $Q=10^{-10}, 10^{-8}, 10^{-6}, 10^{-4}$ 飞対応する垂直波浪曲げモーメントの 長期予測値を読みとって，これらの值を船速及び船の迎角をパラメータとして整理し，船長方向分布及び船長の 関数として示した。

Fig. 7 9 に, 船長 $310 \mathrm{~m}$ の船型について求められた垂直波浪曲げモーメントの長期予測值を $M / \rho g L^{3} B$ の形 
の無次元値として，その船長方向分布を示す。Fig.7 には，フルード数 $F_{r}=0,0.05,0.10,0.15$ の各場合に すべての迎角を考虑に入れた垂直波浪曲げモーメントの長期予測値が, NK（日本海事協会，1967 年版規則に対 する改正規則)，GL (ドイッ船級協会，1970 年版規則)，BV (フランス船級協会，1971 年版規則)， LR（ロイ ト船級協会，1966 年版規則)，NV (ノルウェ一船級協会，1962 年版規則）の各船級協会の緃強度規定に上る垂 直波浪曲げモーメント設計值 ${ }^{20,21)}$ と比較されている。ここで, BV (current case) は 1 年間に 5 6 回遭遇す る波浪を考慮した場合，BV（excep. case）は船の一生に 1 回遭遇すると思われる波浪を考慮した場合を意味す る。これらの図に示した結果によれば, 各船級協会の規定による垂直波浪曲げモーメント設計值は大幅に異なっ ているが，その平均的な值は， $Q=10^{-7}$ に対応する長期予測值，あるいは， $Q=10^{-8}$ に対応する長期予測值に相 当するとみなせるようである。なお，長期超過磪率 $Q=10^{-8}$ に対応する垂直波浪曲げモーメントの長期予測值 について, フルード数 $F_{r}=0,0.05,0.10,0.15$ の各場合に迎角 $\delta$ をパラメータとする長期予測値の船長方向 分布図を Fig. 8 に，また，すべての迎角を考慮した場合にフルード数 $F_{r}$ をパラメータとする長期予測値の船 長方向分们図を Fig. 9 に示す。Fig. 9 には，各船級協会の規定による垂直波浪曲げモーメント設計值も示され ている。

Fig. 10 とは, S.S. 7，5，3 の各断面に働く垂直波浪曲げモーメントの $Q=10^{-10}, 10^{-8}, 10^{-6}, 10^{-4}$ に対応 する長期予測値を $M / \rho g L^{3} B$ の形の無次元值として船長の関数として示し各船級協会の規定による垂直波浪曲げ モーメント設計值と比較している。また，Fig. 11 には，Q=10-8 に対応する垂直波浪曲げモーメントの長期予 測値をフルード数 $F_{r}$ をパラメータとして船長の関数として表わした図を示している。

Fig. 7〜11 に示された結果によれば，垂直波浪曲げモーメント長期予測值の一般的傾向について次のような結 論を得る。

（i）垂直波浪曲げモーメント長期予測傎は正面迎波状態及び追波状態で最も大きく（追波状態の方がわずか に大きい)，横波状態で最も小さい。

（ii）垂直波浪曲げモーメント長期予測值の船長方向分布は船体中央に関して前後対称に近く，船体中央部付 近に最大值が生じる。

（iii）垂直波浪曲げモーメント長期予測值の最大值が生じる位置は，正面迎波状態及びこれに近い状態では船 速の増大によって船体中央より船首方向に移動し，その場合最大值はやや小さくなり，追波状態及びこれに近い 状態では船速の減少によって船体中央より船尾方向に移動し, 最大値はやや大きくなる。横波状態では船速の変 化により最大值の生じる位置及びその大きさはほとんど変化しない。

（iv）垂直波浪曲げモーメント設計值としては，各船級協会の縦強度規定の現状にかんがみ Fig. 7〜9 亿和い てすべての迎角を考慮した場合の長期超過確率 $Q=10^{-8}$ に対応する長期予測値を参考とすればよいと思われる。 垂直波浪曲げモーメントの最大値としては船体中央の長期予測値を採用して美し支えない。また，最大値を船長 の関数として設計值を定めるには, Fig. 10〜11 においてすべての迎角を考虑に入れて $Q=10^{-8}$ に対応する長期 予测值を参考とすればよいと思われる。

船体中央部に働く垂直波浪曲げモーメントの設計值を設定する場合には「北大西洋においてすべての迎角を考 慮に入れて長期超過確率 $Q=10^{-8} \sim 10^{-7}$ に対応する長期予測值」を基準とするのが一般的な考え方となってい るが，このことは，(iv) に述べた結果と合致する。

さて, 福田等 ${ }^{1)}$ は, 垂直波浪剪断力設計値として, 「北大西洋においてすべての迎角を考慮した場合の長期超 過確率 $Q=10^{-6}$ に対応する長期予測值」を基準とするように提案しているが，本論文の 垂直波浪曲げモーメン 卜設計值炡関する結論と比較して, 設計值が同一レベルの危険率に対応寸る值となっていないことがわかる。し かし，波浪荷重設計值設定の際に，危険率の絶対值を心ずしも同一レベルとすべきか否かは，構造強度計算法， 許容応力に対する考え方との関連があり, 簡単には結論を下し難い。この問題については今後十分の検討が必要 である。

\section{4 結 言}

線形ストリップ理論に基づく規則波中の船体応答理諭, 線形重ね合わせの理論に基づく短期不規則波中の船体 応答理論及び大洋の波浪の長期発現頻度資料を利用した船体応答の長期予測法等を総合して, 巨大型油送船船型 を例として波浪中の船体に働く垂直波浪曲げモーメントの長期予測を行ない，その結果を整理検討して垂㨁波浪 
曲げモーメントの設計值推定に関する重要な資料を得た。即ち，垂直波浪曲げモーメントの長期予測值につい て，船長方向分布，船速の影響；波に対する船の迎角の影響，船型の大きさの影響等を明らかにし，また世界の 主要船級協会の規定による重直波浪曲げモーメント設計值と比較して，次のような結論を得た。

（i ）垂直波浪曲げモーメント長期予測值は正面迎波状態及び追波状態で最も大きく（追波状態の方がわずか 飞大きい)，横波状態で最も小さい。

（ii）垂直波浪曲げモーメント長期予測値の船長方向分布は船体中央に関して前後対称に近く，船体中央部付 近に最大值が生じる。

（iii）垂直波浪曲げモーメント長期予測値の最大值が生じる位置は，正面迎波状態では船速の増大によって船 体中央より船首方向に移動し，その場合最大值はやや小さくなり，追波状態では船速の減少によって船体中央よ り船尾方向に移動し，その場合最大值はやや大きくなる。横波状態では船速の変化により最大值の生じる位置及 びその大きさはほとんど変化しない。

（iv）垂直波浪曲げモーメント設計值としては，北大西洋においてすべての迎角を考慮した場合の長期超過確 率 $Q=10^{-8}$ に対応する長期予測值に基ついて設定すればよいと思われる。この問題については, 他の波浪荷重 設計值との関連から今後も十分の検討が必要である。

終りに臨み，本論文に対し終始ご指導を賜わった九州大学福田淳一教授に謹んで感謝の意を表します。また， 本研究の遂行に当りご協力を頂きました三菱重工長崎造船所造船設計部船体設計課長永元隆一氏, 同課塚本 修 氏，森 俊哲氏に深く感謝します。なお, 計算結果の整理，図表作製にご協力を得ました九州大学造船学教室西川 真理子寋, 吉原真里子嬢に謝意を表します。最後に, 本研究の計算は三菱重工業長崎研究所の電算機 “IBM-360” 及び九州大学大型計算機センターの電算機 “FACOM 230-60”によって行なわれたことを付記する。

\section{参 考 文 献}

1）福田淳一，永元隆一，塚本 修，新開明二：波浪中の船体に働らく垂直剪断力の設計值推定，日本造船学 会論文集，第 136 号 (1974).

2）福田淳一，柴田 実，豊田久夫，星隈明吉：規則波中の高速艦艇に動らく曲げモーメント，造船協会論文 集, 第 112 号 (1962).

3）福田淳一，柴田 実，豊田久夫：規則波中の大型油送船の縦強度に関する研究，西部造船会々報，第 26 号 (1963).

4）島田博之，緒方源信，小沼 守：巨大船の波浪縦曲げモーメントおよび剪断力の長さ方向の分布について， 造船協会論文集，第 121 号 (1967).

5) N. Nordenström : Calculations of wave-induced motions and loads, Progress report No.4, A pilot study with the computer program NV 403, Report No.66-11-S, Det Norske Veritas Research Department (1966).

6) E. Abrahamsen : Recent development in the practical philosophy of ship structural design, Publication No.60, Det Norske Veritas (1967).

7) E. Abrahamsen : Structural design analysis of large ships, Trans. SNAME, Vol.77 (1969).

8) J. Fukuda : Theoretical determination of design wave bending moments, Japan Shipbuilding \& Marine Engineering, Vol.2, No. 3 (1967).

9）福田淳一，飯塚正文，緒方源信，小沼 守：巨大船に働らく波浪曲げモーメントの長期分布について，西 部造船会々報, 第 34 号 (1967).

10）福田淳一：長期の波浪曲げモーメント異常值の傾向について，日本造船学会論文集，第 123 号（1968）.

11) E. V. Lewis : Predicting long-term distributions of wave-induced bending moment on ship hulls, SNAME Spring Meeting (1967).

12）佐藤 茂，中村一郎，他 7 名：幅広船の構造強度に関する研究，日本造船学会諭文集，第 134 号 (1973).

13）福田淳一：規則波中の船の縦曲げモーメント(続)，造船協会論文集，第 111 号（1962）.

14）福田淳一：ストリップ理論とその応用，日本造船学会誌，第 485 号 (1969).

15) W. H. Warnsinck : Report of Committee 1 on environmental conditions, Proceedings of 2 nd ISSC, Delft (1964).

16) M. St. Denis and W. J. Pierson Jr.: On the motions of ships in confused seas, Trans. SNAME, Vol.61 (1953).

17) S. O. Rice : Mathematical analysis of random noise, The Bell System Technical Journal, Vol. 24 (1945). 
18）福田淳一，新開明二：不規則波中の船体応答スペクトル計算における二，三の問題，西部造船会々報，第 50 号 (1975).

19) H. Walden : Die Eigenschaften der Meereswellen im Nordatlantischen Ozean, Deutscher Wetterdienst, Seewetteramt, Einzerveröffentlichungen 2, Nr. 41, Hamburg (1964).

20）関西造船協会：関西造船協会ルール検討委員会報告（第 1 報）（1966）.

21）SR 134：船体構浩部材の許容応力に関する研究, 日本造船研究協会研究資料, No. 179 (1973).

Table 1 Main Particulars of a Gigantic Oil Tanker

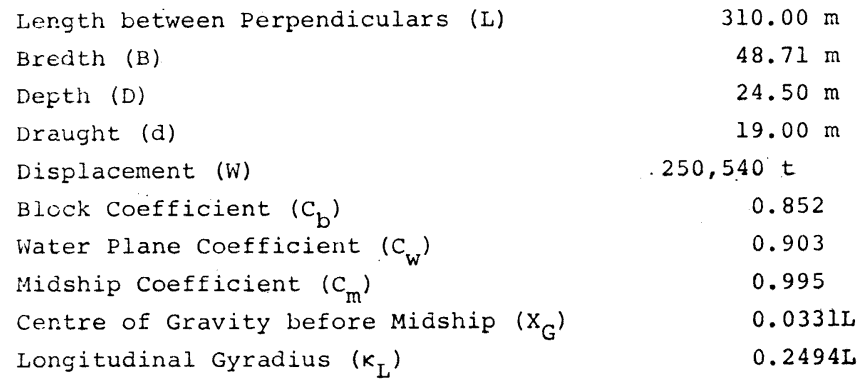

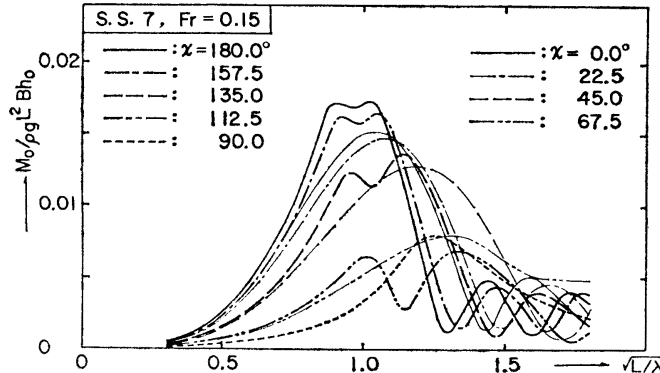

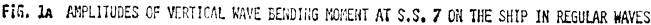
FROM DIFFERENT DIRECTIONS

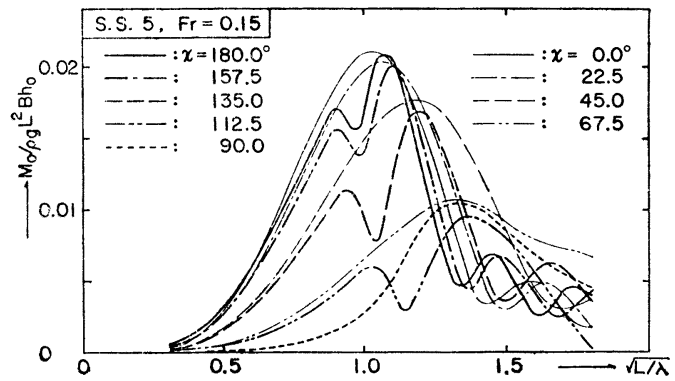

FIG. IB AMPLITUDES OF VERTICAL NAVE BENDING MOMENT AT $S, S, 5$ ON THE SHIP IN REGULAR WAVES FROM DIFFERENT DIPECTIONS

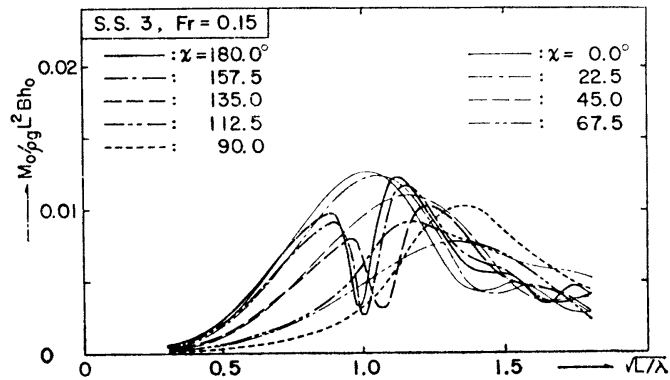

FIG. Ic AMPLITUDES OF VERTICAL WAVE BENDIIIG MOMEHT AT S.S. 3 ON THE SHIP IN REGULAR WAVES FROM DIFFERENT DIRECTIONS

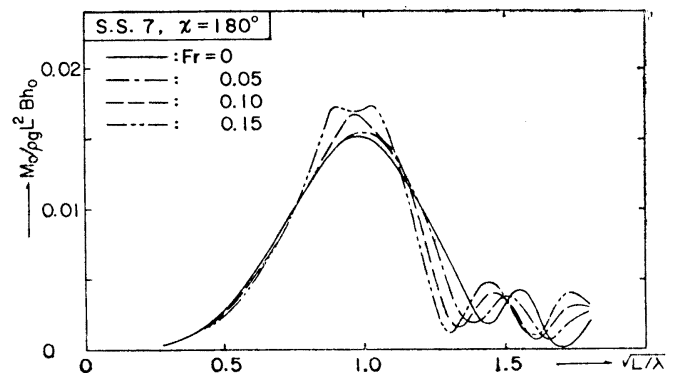

FIG. 2A AMPLITUdeS OF VERIICAL haVE BENDING MOMENT AT S.S 7 ON THE. SHIP IN REGULAR hEAB WAVES

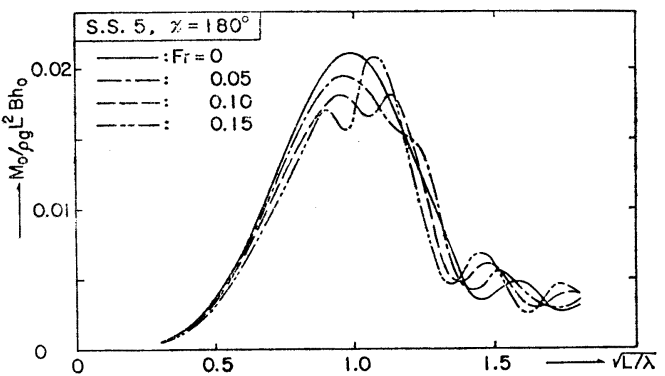

FIG. $2 B$ AMPLITUDES OF VERTICAL NAVE BENDING MONCNT AT S.S. 5 ON THE SHIP IN REGULAR HEAD NAVES

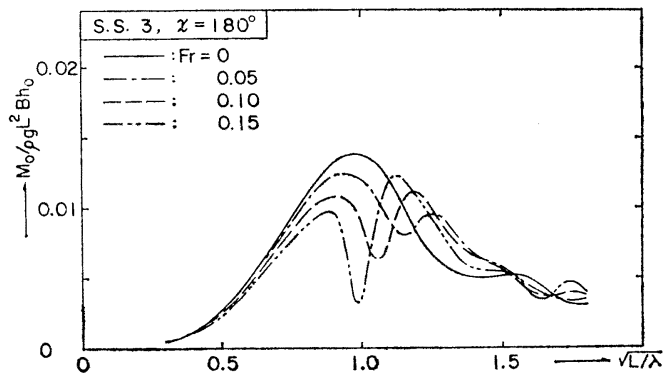

FIG. 26 AMPLITUDES OF Verticat haVE BENDING MOMENT AT S.S. 3 ON THE SHIP IN REGULAR HEAD MAVES. 


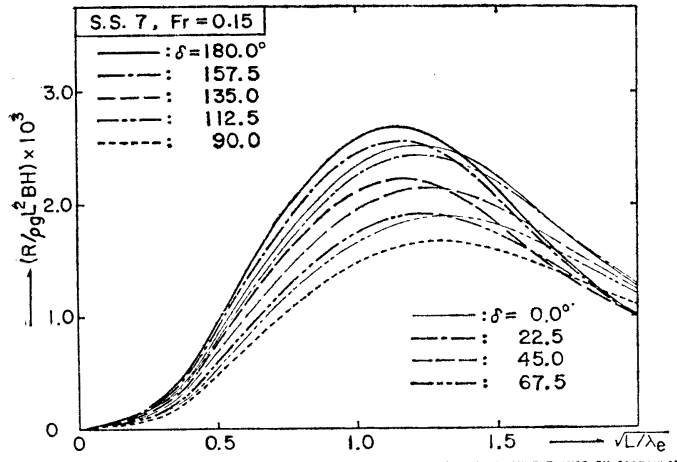

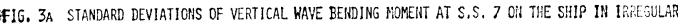
WAVES FOR DIFFERENT HEADINGS

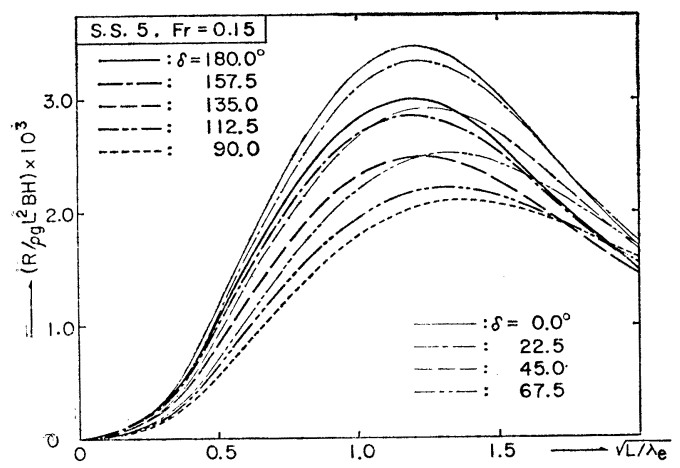

FIG. 3 B STANEARD DEVIATIONS OF VERTICAL WAVE RENDING MOMENT AT S.S. 5 ON THE SHIP IN IRREGULAR HAVES FOR DIFFERENT HEADINGS

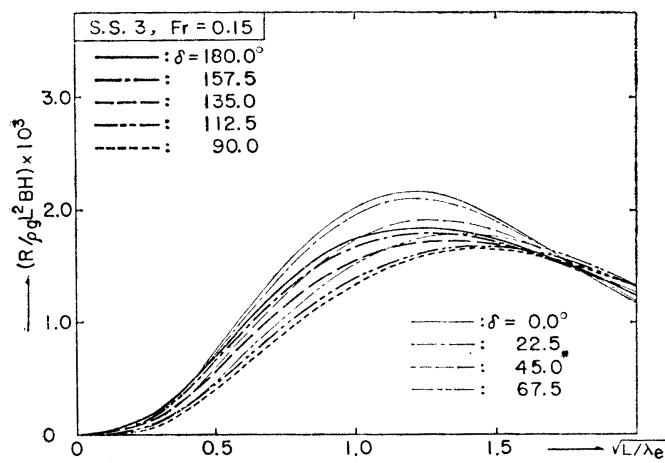

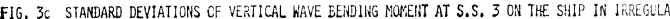
WAVES FOR DIFEEPENT YEADINGS

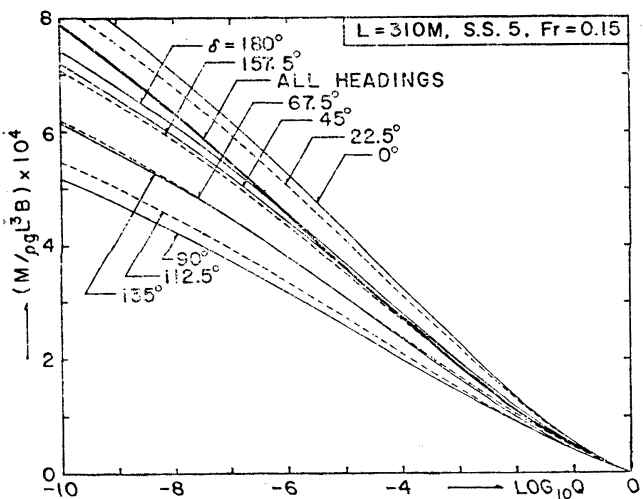

1F16. 5 LONG TERM DISTRIBUTIONS OF VERTICAL WAVE BENDING MONENT AT S.S. 5 CN THE SHIP OF 310 METERS LEHGTH IN THE NORTH ATLWWTIC OCEAN

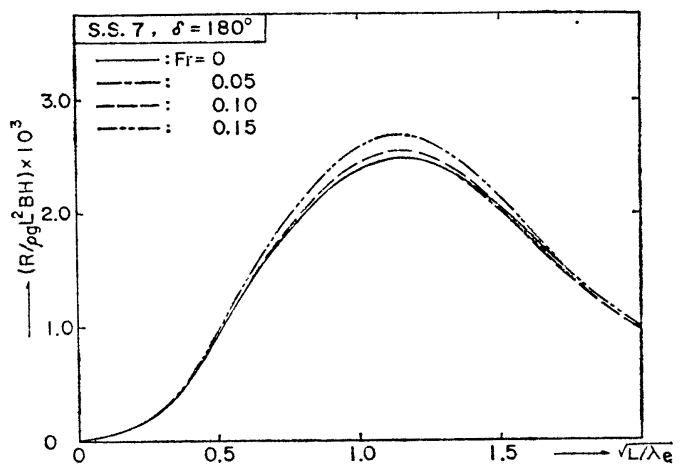

FIG. 4A STANDARD DEVIATIOANS OF VERTICAL WAVE BENDING MONENT AT S.S. 7 CII THE SHIP IN IRREGULAR DEAD WANES

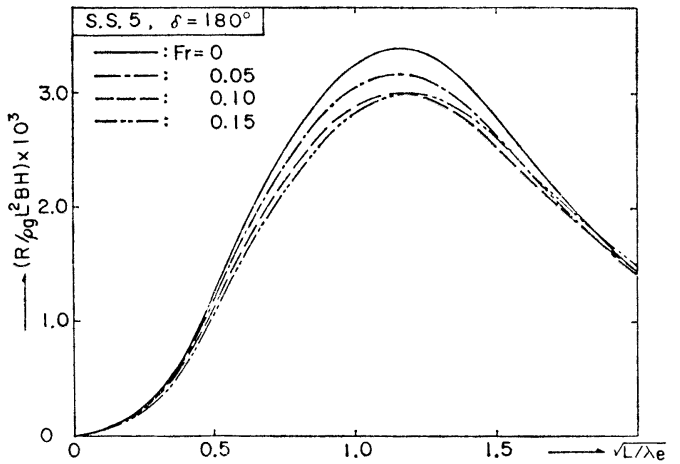

FIG. 4B STAMDARD DEVIATIONS OF VERTICAL WAVE EENDIHG MONENT AT S.S, 5 ON THE SHIP II IMAEGGLAR HEAD KAVES

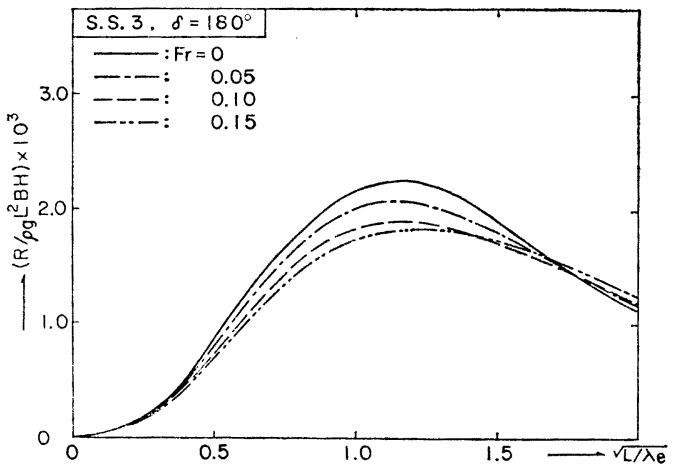

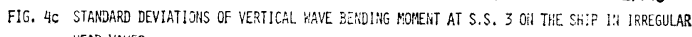
HEAD WAVES

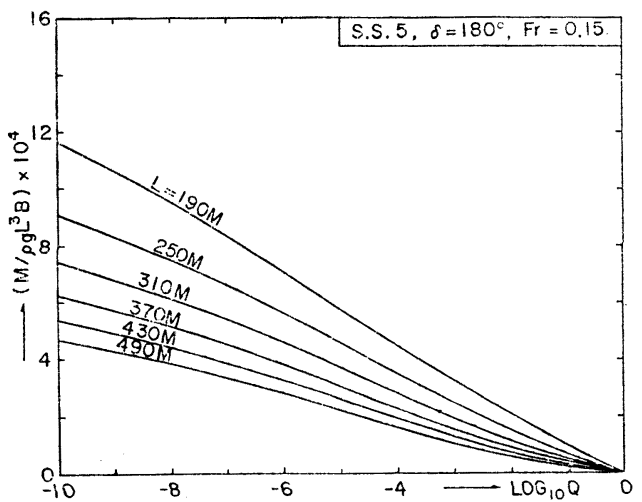

F!G. 6 LONG TERY DISTRIBUTIONS OF VERTICAL WAVE BENDING MONENT AT S.S. 5 ON SINILAR SHIPS OF DIFFERENT LENGTHS IN THE NORTH. ATLANTIC OCEAUI 


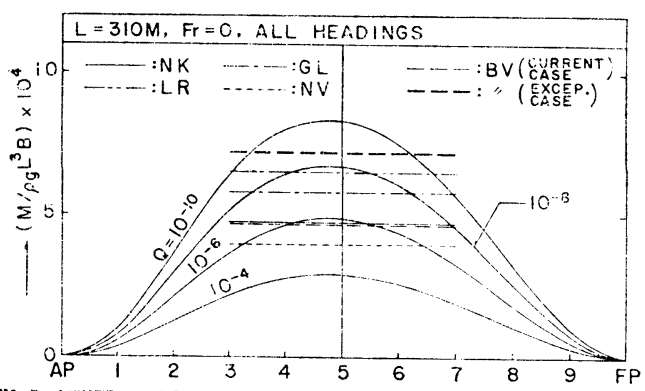

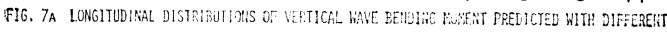

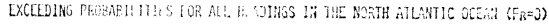

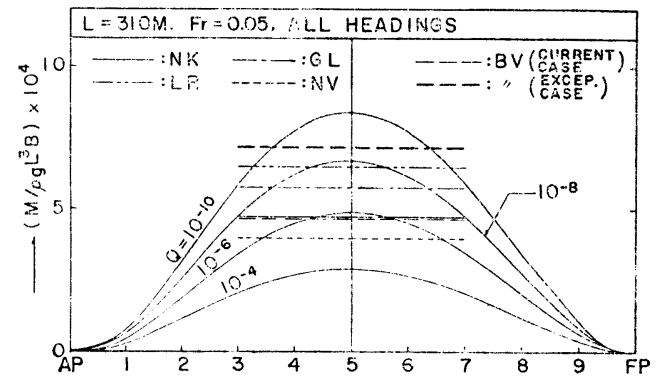

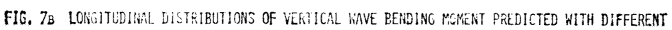

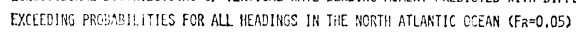

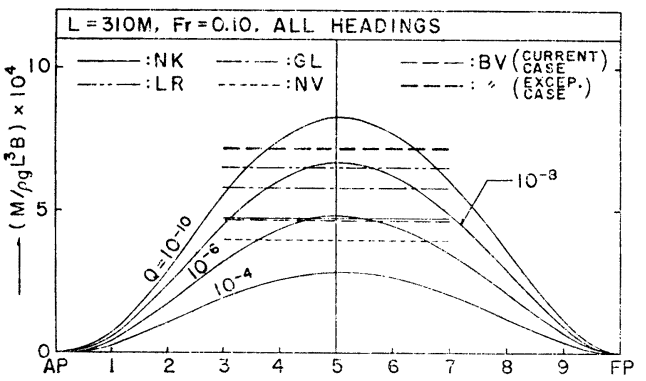

FIG. 7c LONGITUDINAL DISTRIBUTIONS OF YERIICAL WAVE BENDING MOTENT PRCDICTED WITH DiFfERENT

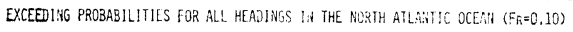

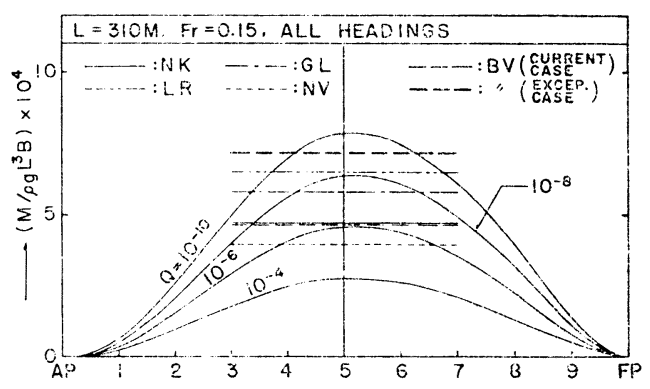

F1G. 7D LOHGITUDiNAL DISTRiBUTIONS OF VERTICAL WAVE BENDIHG MONENT PREDICTED WITH D!FFERENT EXCEEDING PROBABILITIES FOR ALL HEADINGS III THE NGRTH ATLUITIC OCEAN ( $\left.F_{R}=0.15\right)$

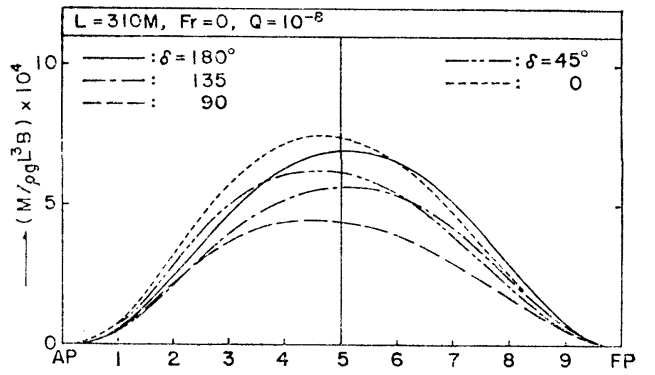

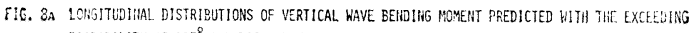
PRORREILITY OF $10^{-8}$ FOR DIFFEREST HEADINGS IN THE HORTH AILANTIC OLCARi $\left(\mathrm{F}^{-}=0\right.$ )

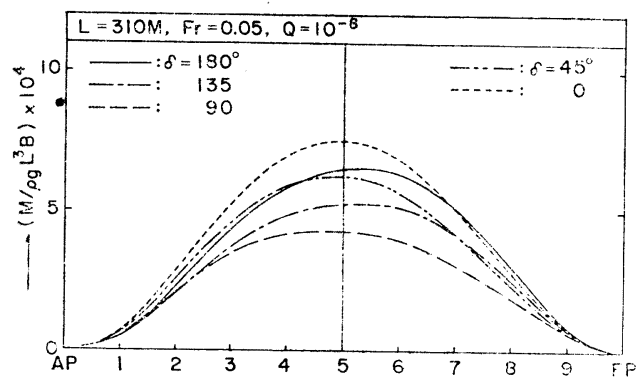

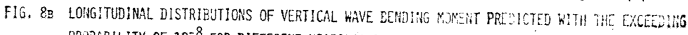

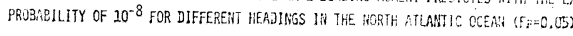

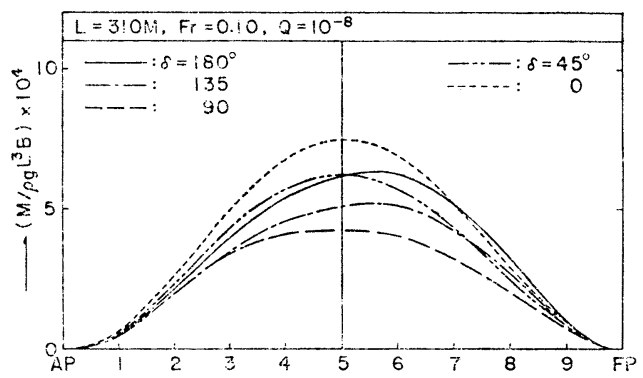

FIG. 8C LONGITUDINAL DISTRISUTIGNS OF VERTICAL HAVE BENDING MOMENT PREDICTED WITH THE EXCEEDING FRCEABILITY OF $10^{-3}$ FOR DIFFEREHT HEADIHOS IN TUE WDRTH ATLANTIC OCEAN ( $\mathrm{F}_{\mathrm{R}}=0.10$ )

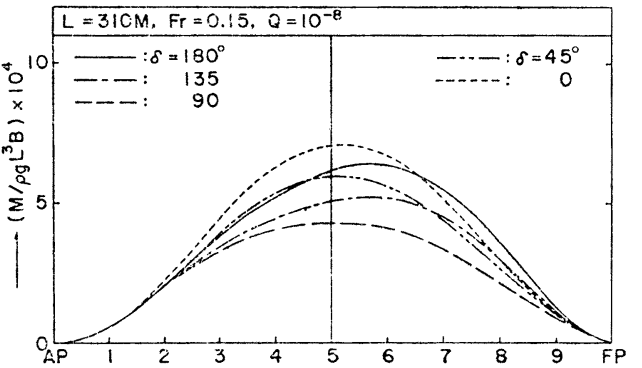

FIG. 8D LONGITLDIHAL DISTRIBUTIONS OF VERTICAL WAVE BENDING MOMENT PREDICTED WITH THE EXCEEIHIO PROBABILITY OF $10^{-8}$ FOR DIFFERENT hEADIHGS IN THE NORTH ATLAHTIC OCERI ( $\left.\mathrm{R}=0.15\right)$ 


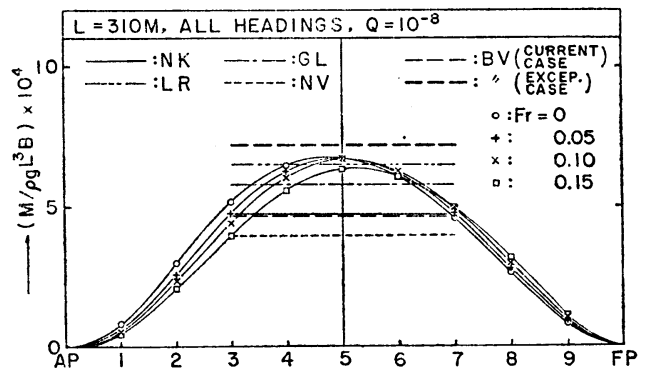

FIG, 9 LONGITUDINAL DISTRIBUTIONS OF VERTICAL WAVE BENDING MOMENT PPEDICTED WITH THE EXCEEDING PROBABILITY OF $10^{-8}$ FOR ALL HEADINGS AT DIFFERENT SPEEDS IN THE NORTH ATLANTIC OCEAN

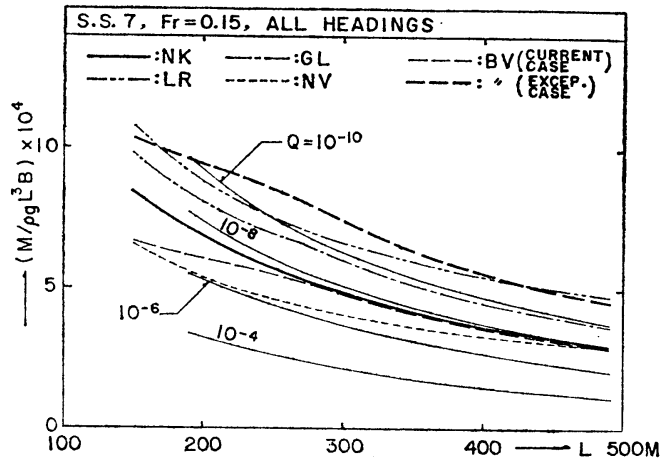

FIG. 10A VERTICAL WAVE BENDING MOHENT AT S.S. 7 PREDICTED WITH DIFFERENT EXCEEDING PROBABILITIE ON SIMILAR SHIPS OF DIFFERENT LENGTHS IN THE NORTH ATLANTIC OCEAN

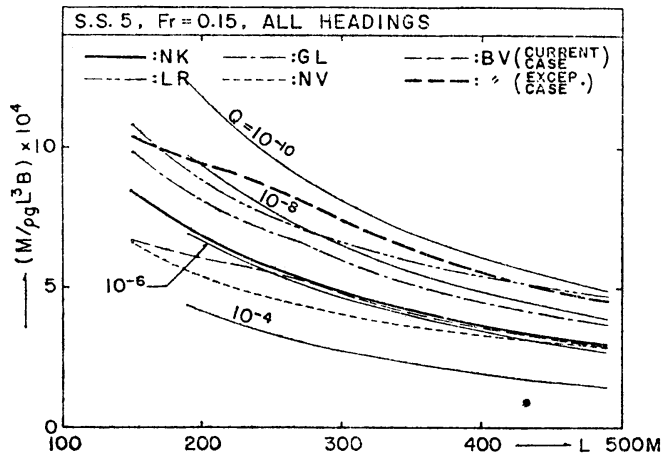

FIG, 10B VERTICAL haVE BENDING MOMENT AT S.S. 5 PREDICTED WITH DIFFERENT EXCEEDiNG PROBABILITIES ON SIMILAR SHIPS OF DIFFERENT LENGTHS IN THE NORTH ATLANTIC OCEAM

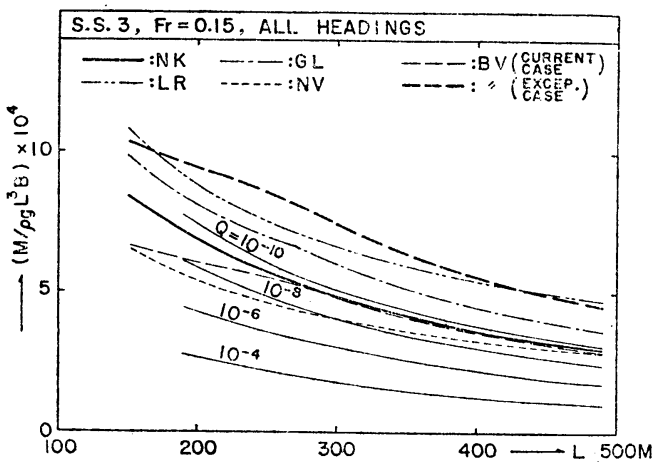

FIG. 10G VERTICAL WAVE BENDING MOMEAT AT S.S. 3 PREDICTED WITH DIFFERENT EXCEEDING PROBABILITIES ON SIMILAR SHIPS OF DIFFEREHT LENGTHS IK THE NORTH ATLANTIC OCEAN

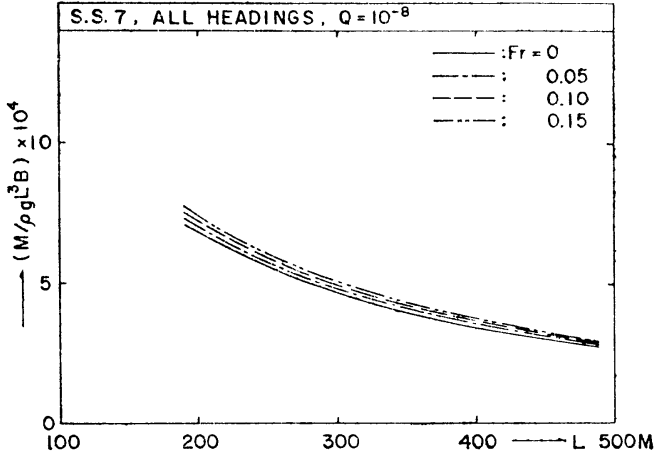

FIG. IT VERTICAL WAVE BENDING MONENT AT S.S. 7 PPEDICTED WITH THE EXCEEDIMG PROBABILTTY OF $10^{-8}$ ON SIMILAR SHIPS OF DIFFERENT LENGTHS IN THE NORIH ATLANTIC OCEAN

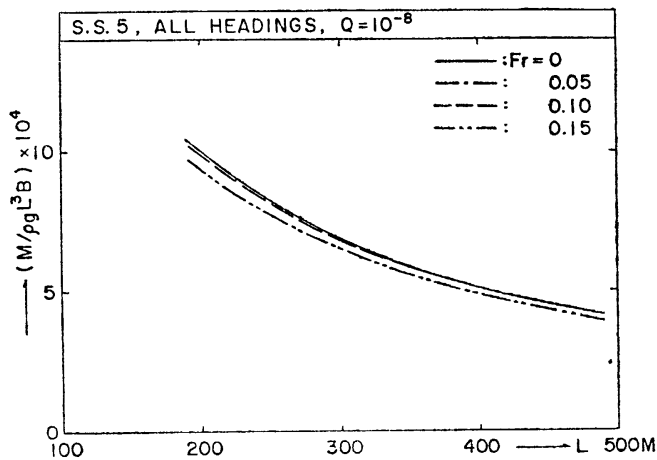

FIG. IIS VERTICAL WAVE BEWINS MYNENT AT S.S. 5 PREDICTED WITH THE EXCEEDING PROBABIHTTY OF

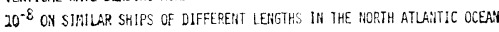

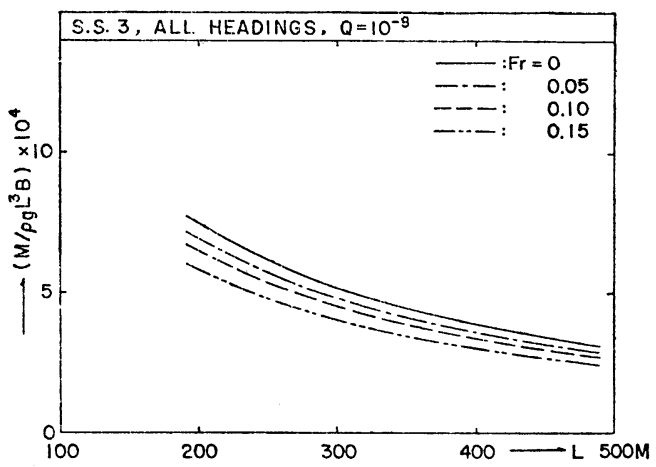

F16. 11C VEPTICAL HAVE PENDING MONERT AT S.S 3 PPEDICTED HITH THE EXCEEDING PROBABILITY OF $10^{-8}$ ON SINILAR SHIPS CF DIFFERENT LENGTHS IN THE NORTH ATLANTIC OCEAN 